\title{
CIVILIZACIJSKE RAZVOJNE STOPNJE IN RAZVOJNI PROBLEMI OBROBNIH OBMOČIJ V SLOVENIJI
}

\author{
Marijan M. KLEMENČıč \\ Oddelek za geografijo, Filozofska fakulteta, Univerza v Ljubljani, \\ Aškerčeva 2, 1000 Ljubljana, Slovenija \\ e-mail: marijan.klemencic@guest.arnes.si
}

\begin{abstract}
Izvleček
$\mathrm{V}$ prispevku je na kratko podan pregled novejših konceptov razvoja obrobnih območij kot izhodišče za opredelitev celovitega vrednotenja obrobnih območij v luči civilizacijskih razvojnih stopenj. Opredeljeni so glavni razvojni problemi in potenciali štirih slovenskih obrobnih pokrajin $\mathrm{z}$ vidika koncepta razvojnih stopenj.
\end{abstract}

Ključne besede: razvojna stopnja, razvojni problemi, obrobna območja, Slovenija

\section{CIVILIZATION DEVELOPMENT STAGES AND DEVELOPMENT PROBLEMS OF PERIPHERAL AREAS IN SLOVENIA}

\begin{abstract}
Short view over peripheral areas contemporary development concepts is used as a deriving point to expose a complex evaluation of peripheral areas through the concept of civilization development stages. The most severe development problems and development potentials of four peripheral areas in Slovenia are defined.
\end{abstract}

Key words: development stage, development problems, peripheral areas, Slovenia 


\section{UVOD}

Hiter gospodarski razvoj, ki ga je prinesla industrializacija, je povzročil močno razlikovanje območij glede na stopnjo družbenogospodarske in prostorske razvitosti. Temeljni dejavnik razlikovanja območij je postala oddaljenost od industrijskih (gospodarskih) središč. Industrializacija je izoblikovala dve skupini območij: osrednja in obrobna (periferna), katerim lahko dodamo še vmesna, prehodna območja. Pokrajinski učinki takšnega razvoja so večplastni in se kažejo v demografski sliki, rabi tal, opremljenosti z infrastrukturo itn. Obrobnim območjem se že nekaj desetletij posveča precejšnja pozornost tako z raziskovalnim delom kot s prizadevanjem oblasti, da bi jim pomagala h gospodarskemu dvigu.

Namen prispevka je opozoriti na to, da je za razumevanje problematike obrobnih območij potrebno upoštevati njihov dosedanji razvoj in ga umestiti v razvojne silnice družbenogospodarskega razvoja.

\section{OPREDELITEV PROBLEMA}

Z vse izrazitejšim uveljavljanjem globalizacije in razvojem tehnologije, predvsem na informacijskem področju, so problemi obrobnih (manj razvitih) območij postavljeni v novo luč. Globalizacija je grobo nadaljevanje koncepta razvoja, kot ga je postavila industrija, na svetovni ravni, ki pa je vzpodbudila nasprotne silnice: poudarjanje lokalnih/regionalnih posebnosti. Zanimiv dialektični skok je posledica tega, da je masovna industrijska proizvodnja (production of scale) dosegla prag zasičenosti svetovnega trga in da je del te proizvodnje moral poiskati druge razvojne možnosti, ki pa izhajajo iz povsem nasprotnih konceptov kot globalizacija. Ta del proizvodnje temelji na potezah kot so: prilagodljivost, kakovost, izpostavljanje posebnosti, uveljavljanje kulturnih vidikov v najširšem pomenu besede (zgodovinske, etnografske, pokrajinske, umetniške itn.). V strokovni literaturi se že nekaj časa uporablja izraz glokalizacija (M. M. Klemenčič, 1999), ki tudi pojmovno izraža dopolnjevanje dveh skrajnih razvojnih silnic: globalizacije in lokalne avtarkije.

$\mathrm{Na}$ družbenogospodarski in celotni pokrajinski razvoj (lokalni, regionalni) je zato potrebno gledati izrecno vsaj $\mathrm{z}$ dveh vidikov: lokalnega (endogenega) in globalnega (eksogenega). Za učinkovito preučitev domačih potencialov pa moramo poseči v preteklost in prek opredelitve dosedanjega razvoja poiskati iztočnice za sodoben razvoj.

\section{POMEN RAZVOJNIH STOPENJ ZA PREOBRAZBO OBROBNIH OBMOČIJ}

Industrializacija je težila $\mathrm{k}$ strukturnemu poenotenju sveta, da bi se dosegli maksimalni (profitni) učinki, zato je prišlo do hitrega in močnega razlikovanja v (relativni) razvitosti območij. Pri tem so utrpela največjo škodo prometno odmaknjena območja in pokrajine, 
ki niso imele večjih zalog pomembnih naravnih virov. Postindustrijski razvoj ponuja razvojne možnosti tudi tem območjem, če znajo uspešno razviti in tržiti svoje, specifične proizvode. Povedano zelo splošno: iz gospodarsko poenotenega sveta se oblikuje mozaik gospodarsko različno usmerjenost območij, vključenih v svetovni gospodarski sistem. Globalizacija postavlja proizvodnji ostre tekmovalne zahteve, ki jih mora sprejeti tudi lokalno gospodarstvo, le-to pa se izpostavlja s kakovostjo pestrih izdelkov in storitev.

Lokalni/regionalni razvoj je način izrabe naravnih in družbenih virov v okviru prevladujočega družbenogospodarskega (civilizacijskega) sistema.

O problemih obrobnih (manj razvitih) območij v dobi industrializacije so objavljene številne razprave, ki poskušajo problem opredeliti s teoretičnega, metodološkega in praktičnega vidika in to že od 50 . let 20 . stoletja dalje. Izdelane so bile številne tipologije, s katerimi avtorji skušajo izpostaviti značilne stopnje razvitosti posameznih območij. Običajno izhodišče je (namišljeno) srednje stanje, praviloma državno povprečje, opredeljeno predvsem z gospodarskimi kazalci, na primer višino dohodka; primer takega pristopa je Klaassenova (1965) tipologija.

Novejše tipologije so celovitejše in skušajo izpostaviti razvojne možnosti. Kot primer naj služi predstavitev štirih najbolj problematičnih tipov območij, kot jih je opredelil Szul (1988):

1. Promocijsko »obnemogla« območja z nizko življenjsko ravnijo in gospodarsko aktivnostjo ter močnim odseljevanjem prebivalstva.

2. Promocijsko »zelo živahna« območja $\mathrm{z}$ nadpovprečno rastjo števila prebivalstva in $\mathrm{z}$ nizko življenjsko ravnijo.

3. Promocijsko »povprečna« območja $\mathrm{z}$ nizko življenjsko ravnijo, stabilizirano gospodarsko dejavnostjo in stagnacijo števila prebivalstva.

4. Pogojno »obnemogla« območja so dobro razvita, a gospodarska aktivnost se jim zmanjšuje zaradi izčrpavanja naravnih virov.

Tipologije so prirejene preučevanim območjem, zato imajo omejeno vrednost. Širšega (splošnejšega) značaja so teoretski koncepti, ki skušajo gledati na problematiko kar nabolj celovito. $\mathrm{V}$ poznih 80 . letih 20 . stoletja so se začele pojavljati raziskave, ki iščejo razvojne potenciale na lokalni in regionalni ravni, kar je bilo povezano $\mathrm{z}$ iskanjem odgovora na vse močnejšo globalizacijo in njene negativne učinke na družbenogospodarski razvoj posameznih območij. Med prvimi so se takšnih raziskav lotili francoski geografi, pa tudi finski in nemški. Cunha (1988) govori o »drugačnem razvoju«, pri katerem gospodarska rast ni več edini cilj, ampak sredstvo za doseganje celovitejšega razvoja; to je,

- da se skrb za stvari nadomesti s skrbjo za ljudi,

- da vodoravno teritorialno povezanost zamenja navpična (funkcijska),

- da makro stopnjo zamenja mikro raven.

Serrate (1991) ugotavlja, da se lokalni razvoj izraža z dinamiko glavnih podjetniških dejavnikov, ki jih je potrebno obravnavati razvojno in sistemsko. V tem okviru opredeljuje pojem lokalni proizvodni sistem (systeme productif local), ki omogoča zaobseči prostor kot enkratno povezanost proizvodnih enot in njihovih medsebojnih odnosov. 
V Nemčiji ima pri opredeljevanju razvojnih možnosti manjših območij pomembno mesto Maier iz Bayreutha, ki v publikacijah Arbeitsmaterialen zur Raumordnung und Raumplanung od zgodnjih 90. let 20. stoletja objavlja analize razvojnih možnosti manjših mest in lokalnih enot. Njihova odlika je predvsem v prakticističnem, planskem pristopu, šibkejše so pa v teoretskih izhodiščih.

$\mathrm{V}$ teoretskem in metodološkem pogledu so pri obravnavi problematike obrobnih (marginalnih, perifernih) območij zelo dejavni finski geografi. Poudarjajo pomen lokalnih dejavnosti in sposobnosti, pri čemer je zelo pomembno vključevanje v različne mreže (Andreoli et al., 1995). Povezanost evropskih obrobnih območij naj bi okrepila njihovo tekmovalno moč v okviru panevropskih regij.

Po Nordgreenovem modelu (1995) naj bi obrobna območja prešla več razvojnih stopenj: od vzajemno enakih funkcijskih regij, nove regionalne oblike, regionalnega sistema, do regionalne povezave. Pomanjkljivost modela je $\mathrm{v}$ tem, da daje prednost območjem, ki imajo sposobnosti in znanje za preobrazbo njihove gospodarske osnove.

Nove poti in načine regionalnega razvoja $z$ upoštevanjem spremenjenih gospodarskih razmer so opredeljene z idejo o razvoju žepov (pocket development) (Bond \& Tykkylainen, 1996; Tykkylainen \& Jussila, 1998), ki se vključuje v teorijo gospodarskih razvojnih žepov. Pristop upošteva velike razlike v stopnji razvitosti, posebno zaradi razlik »družbe znanja«, kjer razlike naraščajo zaradi kakovosti in stopnje znanja posameznikov in gospodarskih družb na posameznem območju.

$\mathrm{V}$ evropskem okviru (EU) ne moremo mimo obeh razvojnih programov LEADER, ki v veliki meri vključujeta sodobna teoretska izhodišča pri razvoju obrobnih območij.

\section{OBROBNA OBMOČJA IN SLOVENSKA GEOGRAFIJA}

Po zaslugi Vladimirja Klemenčiča se slovenska geografija uvršča med tiste evropske geografije, ki so prve zaslutile in opredelile problematiko neenakomernega družbenogospodarskega razvoja posameznih območij. V Sloveniji so bile razvojne razlike najprej prikazane prek velikih razlik v demogeografskem razvoju (Klemenčič V., 1971). Kmalu za tem so bile izvedene raziskave, ki so skušale na celovit način opredeliti naravo nerazvitosti in izpostaviti temeljne razvojne dejavnike (Klemenčič M., ur., 1980). Kljub temu, da je preučevanje razlik $\mathrm{v}$ razvoju slovenskih pokrajin stalnica $\mathrm{v}$ slovenski geografiji, pa študije niso vnesle novih teoretskih izhodišč, ki bi presegle koncept raziskav iz 80 . let 20. stoletja. Raziskave so se ukvarjale s posamičnimi vidiki nerazvitosti (demografski problemi, zaraščanje kulturne pokrajine) in z ugotavljanjem regionalnih razlik s pretežno gospodarskimi kazalci. Vzpodbuden korak na področju preučevanja obrobnih območij je storila Benkovičeva (2003). Njena analiza strukturnih problemov depopulacijskih območij v Sloveniji nudi kakovosten okvir za teoretsko poglobljeno obravnavo mehanizmov prostorskega razvoja v Sloveniji. 


\section{REGIONALNI RAZVOJ V LUČI RAZVOJNIH STOPENJ}

Ugotovili smo že, da je za učinkovit razvoj posebno obrobnih območij potreben celovit pristop, znotraj katerega je potrebna prilagodljivost, aktiviranje domačih razvojnih potencialov in vključevanje v različne mreže, tako znotraj območja kot na širšem območju. Pri teoretičnem opredeljevanju razvojnih problemov ne moremo mimo vsaj dveh pristopov: sistemskega in genetičnega.

Sistemski pristop omogoča $\mathrm{v}$ horizontalni perspektivi (prostorska diferenciranost) kar najbolj realno predstaviti vse bolj zapletene odnose med razvojnimi dejavniki (omrežje mrež). Vertikalni (časovni) genetski pristop pa omogoča časovno sledenje pomena razvojnih dejavnikov in najti način za razumevanje pomena razvojnih struktur.

Oba pristopa zahtevata celovit pristop, ki ga omogoča najširši (prostorsko-časovni) pogled. S konceptom razvojnih stopenj civilizacije lahko v polni meri zaobjamemo oba pogleda, kar omogoča dokaj objektivno vrednotenje razvojnih stopenj posameznih območij. Pokrajina je neposredna odslikava splošnih razvojnih stopenj, ki smo jih opredelili kot agrarna, industrijska in informacijska.

Agrarna razvojna stopnja, sloneča pretežno na samooskrbnem kmetijstvu s številnimi različicami (tržno kmetijstvo, gozdarstvo, neagrarne dejavnosti). Družba je bila na videz socialno homogena, $v$ podrobnostih pa zelo diferencirana $\mathrm{z}$ majhnim številom hierarhičnih stopenj. Gospodarska struktura in izgled pokrajine sta bili zelo pestri, poselitev izrazito razpršena.

Industrijska razvojna stopnja teži h točkasto-koridorski regionalni strukturi in torej k destrukciji pokrajinske strukture predhodne razvojne stopnje. Nacionalne države so nosilke moči, ki jo suvereno uveljavljajo na vseh področjih in na vseh stopnjah upravnih enot. Gospodarstvo in družba sta strukturirani v jasno razvidnem hierarhičnem ustroju. Izrazita delitev dela vodi na eni strani $\mathrm{k}$ homogenizaciji (globalizaciji) vseh oblik družbenogospodarskega življenja, na drugi strani pa $\mathrm{k}$ velikim razlikam $\mathrm{v}$ stopnji razvoja ožjih in širših območij.

Informacijska razvojna stopnja uveljavlja razvojni model, ki je mešanica obeh predhodnih. Kaže se v opazni destrukciji hierarhičnega modela zgradbe družbe in gospodarstva industrijske dobe. Uveljavlja se vse bolj zapletena mrežna struktura, ki se bolj kot na zunaj kaže $\mathrm{v}$ prikritih razmerjih med razvojnimi dejavniki. $\mathrm{V}$ pokrajini se to odraža $\mathrm{v} »$ koncentrirani dekoncentraciji« dejavnosti (gospodarska struktura, raba tal, poselitev itn.). Namesto meja (jasnih razmejitev) stopajo v ospredje odnosi, torej povezovanje. V iskanju možnosti preživetja in socialno-gospodarskega dviga se posamezniki in skupine obračajo celo h gospodarskim modelom, ki so bili značilni za agrarno razvojno stopnjo (raznovrstnost proizvodov, prilagodljivost proizvodnje zahtevam potrošnika itn.) in $\mathrm{v}$ posodobljeni obliki obujajo $\mathrm{v}$ industrijski dobi preživete izdelke in običaje.

V sodobni (informacijski) dobi razvojne silnice izhajajo iz dveh smeri: globalizacijske in lokalne. Optimalen lokalen (regionalen) razvoj je takrat, ko sta obe silnici v ravnotežju. Prevlada vplivov globalizacije postavlja lokalno raven v gospodarsko odvisnost, njihova izključitev pa vodi v avtarkijo in s tem v družbenogospodarsko nazadovanje (osamitev). 
Pri obrobnih območjih je namesto globalizacijskih vplivov primerneje uporabljati izraz zunanji vplivi, ki so posredno globalizacijski. $V$ večini primerov gre namreč za delovanje širših domačih dejavnikov, ki so vključeni v globalizacijske procese (turizem, vikendaštvo, industrijski obrati, razne oblike podjetništva).

Pri razvoju obrobnih območij torej ne gre le za modernizacijo znotraj industrijske razvojne stopnje, ampak za preobrazbo, za uveljavljanje novih razvojnih konceptov, ki jih prinaša informacijska doba. V takem položaju so razvojne teorije, posebno ekonomske, ki slonijo na širjenju novosti (innovation diffusion) ali na primerjalnih prednostih, izgubile pravi smisel. Potreben je že večkrat omenjen celovitejši pristop, ki izhaja iz stanja obravnavanega območja v odnosu do (naj)širšega prostora.

\section{IZHODIŠČA ZA OPREDELJEVANJE FUNKCIJSKIH PROSTORSKIH ENOT}

Agrarno obdobje je postavljalo $\mathrm{v}$ ospredje pokrajinsko homogenost kot izhodišče za opredeljevanje prostorskih funkcijskih enot. Industrijska doba postavlja gravitacijska območja kot temeljni dejavnik organizacije prostora, ne glede na naravne razmere. V informacijski dobi se oba predhodna koncepta dopolnjujeta, pri čemer je v ospredju še vedno gravitacijski vidik, vendar v mnogo kompleksnejši obliki. Obrobna, manj razvita območja v podobi razvojnih žepov dobivajo svoje razvojne možnosti v postulatih sodobne civilizacije: varovanje in razvijanje tradicije, vrednotenje lokalnih posebnosti, ohranjevanje naravnega okolja in kulturne pokrajine.

$\mathrm{V}$ industrijski dobi se je problem manjše razvitosti reševal tako, da se je obrobna območja skušalo čimbolj vključiti v proizvodno in infrastrukturno mrežo najbolj razvitih območij, torej v zmanjševanje razlik gospodarske učinkovitosti posameznih območij. Takšen pristop ni odpravljal nerazvitosti, ampak jo je skušal le omiliti. Industrijski način proizvodnje, usmerjen izrazito profitno, je uveljavljal relativno monostrukturno gospodarsko strukturo, $\mathrm{v}$ kateri prometno bolj odmaknjena in $\mathrm{z}$ naravnimi viri revna območja niso imela možnosti enakopravnega tekmovanja $\mathrm{z}$ osrednjimi območji.

$\mathrm{V}$ informacijski dobi se poleg načela pridobivanja profita vse bolj uveljavlja pojem kakovosti življenja, kar odpira obrobnim območjem nove razvojne možnosti. Bivanje $\mathrm{v}$ nekaj deset kilometrskem pasu od središč ne pomeni več slabosti, ampak vedno bolj prednost, vsaj za nekatere socialne skupine. Vse več ljudi daje pri izbiri bivališča prednost nematerialnim vrednotam (mir, stik $\mathrm{z}$ naravo, umirjen način življenja, druženje $\mathrm{v}$ majhnih lokalnih skupnostih itn.) prednost pred materialnimi. Na ta način se dotedanja izrazito homogena in neugodna socialna sestava prebivalstva (nekvalificirani, ostareli) izboljšuje in postaja vse bolj pestra.

Kot izhodišče za opredeljevanje funkcijskih enot sodobne družbe ne moremo mimo že iz industrijskega obdobja podedovanih obrobnih območij, to je prometno odmaknjenih hribovitih, kraških in obmejnih območij. Tako smo ponovno, kot v agrarni dobi, pri pokrajinsko homogenih območjih, ki so bila posebno v industrijski dobi zapostavljena 
zaradi neugodnih naravnih pogojev za tržno učinkovito blagovno proizvodnjo in prometno odmaknjena.

Za osvetlitev razvojnih problemov in razvojnih možnosti v luči razvojnih stopenj so bila izbrana nekatera najbolj značilna slovenska obrobna območja: Goričko, Haloze, Kozjansko in Brkini.

\section{GORIČKO}

Gričevnata pokrajina, zgrajena pretežno iz sedimentov terciarne (pliocenske) starosti (peski, glina, prod) s slemeni, ki jih ogroža suša in mokrotnimi dolinskimi dni ne nudi dobrih pogojev za kmetovanje. V družbenogeografskem pogledu je poleg obrobnega geografskega položaja pomembna dediščina pripadnosti območja ogrskemu delu habsburške monarhije, ki je dala odločilen pečat predvsem agrarni strukturi. Rezultanta omenjenih, predvsem neugodnih življenjskih razmer, je poldrugo stoletje prisotno odseljevanje, zlasti sezonskega značaja. (Ob)robnost Goričkega je vidna tudi v geografski preučenosti območja, saj ni doživelo temeljitejše celovite geografske obdelave. V ospredju zanimanja je predvsem demogeografska problematika, pri kateri prednjačijo izseljeništvo (n.pr. Olas, 1963; 1972), demografska struktura (n.pr. Počkaj Hrovat, 1992) in problematika madžarske narodne skupnosti.

Oglejmo si nekatere pomembne dogodke, ki so vplivali na družbenogospodarsko in prostorsko podobo Goričkega v zadnjem poldrugem stoletju.

1850 - začetek množičnega odhajanja na sezonsko delo na Madžarsko (kmetijstvo) in v Avstrijo (zidarstvo);

1880 - bolezen uniči vinsko trto;

1890 - izseljevanje v Ameriko;

1918 - Goričko preide v sklop (kasnejše) Jugoslavije;

1920 - predvsem sezonsko izseljevanje v Nemčijo in Francijo;

1960 - začetek močnega zdomskega toka proti Avstriji in Nemčiji.

Glavni razvojni problemi: demografska izčrpanost zaradi izseljevanja in zdomstva ter socialnoekonomska dvojnost: ostarelo in revno domače prebivalstvo na eni strani, na drugi pa ostareli zdomski povratniki s sorazmerno ugodnim življenjskim standardom.

Znaki oživljanja razvoja: vzdrževanje in ohranjanje drobne gospodarske dejavnosti ter razvoj terciarnega sektorja v občinskih središčih (Grad, Rogašovci, Kobilje).

\section{HALOZE}

Miocenski sedimenti panonskega morja (peščeni laporji in kremenovi peščenjaki), močno razrezani v višje zahodne (Gozdne) in nižje vzhodne (Vinorodne) Haloze že s poimenovanjem nakazujejo (ne)primernost naravnih razmer za kmetijsko rabo. Grabe s strmi- 
mi pobočji, na katerih pogosto prihaja do zemeljskih usadov in plazov predstavljajo zelo krute življenjske razmere domačemu prebivalstvu, ki jih otežuje še pomanjkanje vode in izredno slabe prometne poti. Posledično je (bilo) območje tradicionalno gospodarsko zaostalo s težkimi socialnimi razmerami (viničarstvo), kar je odlično prikazal Bračič (1967; 1982). Ker v bližini ni bilo industrijskih središč, se je z odseljevanjem siromašila demografska in gospodarska moč območja.

Haloze zaradi stalne gospodarske odvisnosti od zunanjih gospodarskih dejavnikov (zemljiška veleposest, industrija $\mathrm{v}$ zadnjih desetletjih) niso doživele znatnejših razvojnih ciklov, ampak neprekinjeno zmanjševanje razvojnih potencialov. Pomembnejši mejnik je predstavljala dokončna odprava viničarskih odnosov po drugi svetovni vojni in hkratno odseljevanje v industrijska središča. Šele od 70. let 20. stoletja je skromna industrija na robu Haloz delu prebivalstva omogočila dnevno migracijo.

Haloze lahko $\mathrm{v}$ veliki meri primerjamo $\mathrm{z}$ razvojem dobršnega dela francoskega podeželja, ki je od francoske revolucije dalje doživljalo izseljevanje prebivalstva in posledično zaraščanje kulturne pokrajine, kar je Beteille (1981) imenoval dezertifikacija oziroma prazna (opustela) Francija.

Razvojni potenciali so sila skromni. Edini pomembnejši je demografska struktura, ki je $\mathrm{v}$ primerjavi $\mathrm{z}$ drugimi slovenskimi obrobnimi pokrajinami sorazmerno ugodna. Bolj kot $\mathrm{v}$ drugih podobnih pokrajinah se je od 90 . let 20. stoletja dalje zmanjšalo izseljevanje. Zaradi splošne manjše gospodarske razvitosti sosedstva pa se je bati, da domače prebivalstvo brez večje zunanje pomoči ne bo moglo izpeljati pomembnejših razvojnih projektov.

\section{KOZJANSKO}

Razvodna, reliefno razgibana pokrajina, ki jo sestavljajo vzporedniško potekajoča slemena in podolja je zgrajena pretežno iz pasov laporja, apnenca, peščenjakov, peska in koglomeratov. Klimatski pogoji v povezavi z nadmorsko višino omogočajo pestro kmetijsko rabo, od živinoreje, sadjarstva, do vinogradništva na vzhodu. V zadnjih dveh stoletjih je območje nihalo med obmejnostjo in obrobnostjo. Prva je pospeševala trgovino, druga je pomenila odmik Kozjanskega od gospodarskih središč. Razvita trgovina in obrt od srednjega veka dalje sta pokrajini vtisnila raznovrstno dediščino, ki je z izseljvanjem prebivalstva po drugi svetovni vojni izgubila ves pomen; Kozjansko se je uvrstilo med gospodarsko najmanj razvite slovenske pokrajine. Potres je prinesel obnovo domov, kar je predstavljalo le lepo zunanjo fasado vse slabše demografske sestave in dodatno zanemarjanje etnografske dediščine.

Pomembnejši dogodki za razvoj Kozjanskega v zadnjih 150 letih so naslednji:

1850 - upadanje gospodarskega razcveta in trgovine s Hrvaško;

1850 - 1945 - stagnacija kmetijstva, stagnacija in propad neagrarnih dejavnosti;

1945 - začetek močnega izseljevanja v industrijska središča;

1974 - potres, prenova zgradbene strukture;

1980 - pojavljanje izoliranih razvojnih točk (kmetijstvo, mali indust. obrati, obrt, turizem). 
Znaki razvojnih sprememb ob nizki razvojni ravni gospodarstva $\mathrm{z}$ odmiranjem tradicionalnega kmetijstva so zametki sodobnega gospodarstva (vzreja divjačine, prodorni obrtniki, primeri vrhunske kulinarike) in vključevanje kulturne dediščine (krajinski park) v koncept endogenega razvoja, ki mu bližnji Podčetrtek nudi dodatne razvojne izzive.

$\mathrm{V}$ razvojnem pogledu se je na podlagi statističnih podatkov o zaposlitveni sestavi prebivalstva oblikovala teza o možnem prehodu iz agrarne v terciarno družbo brez močnejše industrializacije (M. M. Klemenčič, 1993, str. 132). Teza ostaja aktualna v sedanjih razmerah tudi za ostala obrobna območja.

Glavni razvojni problemi so povezani s prevlado ostarelega in nizko izobraženega prebivalstva ter s slabimi prometnimi povezavami z večjimi središči v sosedstvu.

\section{BRKINI}

Do $800 \mathrm{~m} \mathrm{n}$. v. visoko flišno hribovje, ki ima v primerjavi z obdajajočim kraškim svetom sorazmerno ugodne naravne pogoje za kmetijstvo; posebno sadjarstvo, kazijo jih le posledice lege hribovja med kontinentalnimi in sredozemskimi vremenskimi vplivi (pozebe, žled). Gospodarski razvoj Brkinov je bil usodno povezan z gospodarskim in političnim razvojem sosedstva. Gospodarska navezanost na Trst in sezonsko zaposlovanje sta omogočila gosto poselitev hribovja. Spremembe političnih meja so Brkinom zadale težak udarec. Naslednjega je zadala šibka gospodarska razvitost bližnje in širše okolice, ki je domačine gnala $\mathrm{v}$ izseljevanje.

Zanimiv gospodarski razvoj je vzbudil precejšnje zanimanje geografov za Brkine, posebno v polpreteklem obdobju, ko so nastale odlične študije (Klemenčič, 1959; Moritsch, 1969; Keber, 1971).

Pomembnejši dogodki, v družbenogospodarskem in prostorskem razvoju Brkinov v zadnjih dveh stoletjih.

1890 - izseljevanje v ZDA;

1918 - Brkini pridejo pod Italijo, gospodarski upad in izseljevanje v Argentino;

1945 - začetek izseljevanja v Avstralijo in v primorska mesta;

1991 - omejitev gospodar. stikov domačinov s Hrvaško (Reko) zaradi carinskih predpisov.

Glavni razvojni problem Brkinov je demografska izčrpanost, ki pa občasno dobiva sicer skromne »injekcije« predvsem s porokami doseljenega prebivalstva. Razvojni potencial se kaže vsaj na dveh področjih: izrabi dediščine (sadjarstvo, posebno pridelava in prede-lava sliv, narodno blago) in ugodne prometne lege blizu obmorskih mest in sodobnih cestnih povezav.

\section{ZAKLJUČEK}

Iz kratkega pregleda so razvidne velike razlike $\mathrm{v}$ družbenogospodarskem razvoju obravnavanih območij v zadnjih 150 letih, ki so bila odločilna za sedanje razmere. 
Pokrajinska homogenost nudi območju enotne razvojne izzive, čeprav je razdeljeno na več občin ali pa je celo brez lastnih občin (Haloze, Brkini).

Razlikujemo lahko pokrajine, ki imajo »spomin« na gospodarski razcvet v preteklosti (Kozjansko, Brkini), druge, ki so živele s kombiniranjem domačega gospodarstva $\mathrm{z}$ zaposlovanjem izven domače pokrajine (Goričko, deloma Brkini) ter pokrajine, ki so bile stalno $\mathrm{v}$ odvisnem položaju in se oklepale skromnega tradicionalnega kmetijstva (Haloze).

Vsaj občasno sledenje splošnim razvojnim stopnjam, ki se je kazalo v uveljavljanju neagrarnega gospodarstva, pokrajinam daje boljše razvojne možnosti. Pokrajine z gospodarskim razcvetom $\mathrm{v}$ preteklosti imajo namreč praviloma še ohranjeno pozitivno identiteto, ki je dobro izhodišče za razvoj. Poleg tega je pretekli razvoj povzročil socialno in gospodarsko diferenciacijo ter razvoj infrastrukture, zaradi česar je lažja gospodarska revitalizacija (Kozjansko, Brkini).

Dolgo ohranjanje gospodarske monostrukture agrarne dobe, celo prek celotne industrijske faze, pomeni temeljito osiromašenje regionalne strukture (Haloze), kar otežuje sodoben razvoj.

Zdomstvo in izseljeništvo je vsaj posredno ugoden razvojni dejavnik zaradi vnašanja novosti iz gospodarsko razvitih dežel.

\section{Literatura:}

Andreoli, M., Gouerec, N., Tellarini, V., 1995: Percorsi di sviluppo in un area marginale: fattori locali et non. V: Miele, M., Rovai, V. (ur.): Tendenze globali et tendenze locali nei processi di sviluppo: Modelli interpretativi a confronto. Il Borghetto, Pisa.

Benkovič, M., 2003: Strukturni problemi depopulacijskih območij v Sloveniji. Magistrsko delo. Oddelek za geografijo, Filozofska fakulteta, Univerza v Ljubljani.

Beteille, R., 1981: La France du vide. LITEC, Paris.

Bond, D., Tykkylainen, M., 1996: Northwestern Russia: a case study in »pocket« development. European Business Review 95, 5, 55-61.

Bračič, V., 1967: Vinorodne Haloze, socialno-geografski problemi s posebnim ozirom na viničarstvo. Obzorja, Maribor.

Bračič, V., 1982: Gozdnate Haloze. Obzorja, Maribor.

Cunha, A., 1988: Systemes et territoire: valeurs, concepts et indicateurs pour un autre development. L, espace geographique 17, 3, 181-198.

Keber, Š., 1971: Brkini. Diplomska naloga. Oddelek za geografijo, Filozofska fakulteta, Univerza v Ljubljani.

Klaassen, L., 1965: Area economic and social redevelopment: guidelines for programmes. OECD, Paris.

Klemenčič, M., M. (ur.), 1980: Manj razvita območja Zahodne Slovenije. Inštitut za geografijo Univerze v Ljubljani. 
Klemenčič, M., M., 1993: Družbenogospodarski razvoj obmejnih območij v Sloveniji. V: Geografski aspekti obmejnosti in regionalnega razvoja. Dela 10, 127-134, Oddelek za geografijo Filozofske fakultete v Ljubljani.

Klemenčič, M., M., 1999: Slovenija v globalizacijski pasti. V: Razvojne možnosti Slovenije. Bodočnost mest. Dela 14, 45-52, Oddelek za geografijo Filozofske fakultete v Ljubljani.

Klemenčič, V., 1959: Pokrajina med Snežnikom in Slavnikom. SAZU, Ljubljana.

Klemenčič, V., 1971: Prostorska diferenciacija Slovenije po selitveni mobilnosti prebivalstva. Geografski zbornik 12, 135-220.

Moritsch, A., 1969: Das nahe Triester Hinterland. Zur wirtschaftlichen und sozialen Entwicklung vom Beginn des 19. Jahrhunderts bis zur Gegenwart. Veroeffentlichungen des Instituts fuer osteuropaeische Geschichte und Suedostforschung der Universitaet Wien, Band 7.

Nordgreen, R., 1995: Regionar, regioninndeling og regionalisering. Lillehammer College, Working paper 8, Lillehammer.

Olas, L., 1963: Migracije Prekmurcev v štajerski del Pomurja. Geog. vestnik 35, 15-33.

Olas, L., Vpliv migracij na socialni in prostorski razvoj Prekmurja. V: Geografski simpozij o severovzhodni Sloveniji. Geogr. Slovenica 2, 52-63, Obzorja, Maribor.

Počkaj Horvat, D., 1992: Geografska tipizacija demografskih območij v subpanonski severovzhodni Sloveniji. Magistrsko delo. Oddelek za geografijo filozofske fakultete, Univerza v Ljubljani.

Serrate, B., 1991: Industrialisation, development et territoire: 1,exemple d,Annecy. L, anallyse du development economique local: une relecture des hierarchies spatiales. Revue de Geographie Alpine 89, 2, 69-84.

Szul, R., 1988: Mechanismy rozwoju regionalnego - przyklad Polski, Hiszpanii i Jugoslawii. V: Gospodarka prezstrzenna, region, lokalnosć. Biuletyn KPZK PAN 138, 148-193, Warszawa.

Tykkylainen, M., Jussila, H., 1998: Potentials for innovative restructuring of industry in Northwestern Russia. Fennia 176:1, 223-245.

\section{CIVILIZATION DEVELOPMENT STAGES AND DEVELOPMENT PROBLEMS OF PERIPHERAL AREAS IN SLOVENIA}

\section{Summary}

Homogeneous economic structure of the whole world reflects in different types of economicaly developed areas. The existence of less developed (peripheral) areas in the period of industrialization and globalization looks like obvious. The new development stage based on information technology offers possibilities to change the socio-economic 
structure of peripheral areas by the activity the local development actors and sources and to promote specific products and services.

The evaluation of development stages and development cycles of four hilly and mountainous peripheral areas shows a great meaning of the integrity of local economy in the last century into wider economic procesess for a new concept of development.

Landscape homogeneity (hilly, mountainous, carst) offers to the area equal development challenges, nevertheless the area is divided by more communities.

In the last century three basic (civilization) development stages have occured: agrarian, industrial and informational. Each one have had and have different way of economic activity, way of life and land-use pattern. The most evident concepts of development stages mentioned are: deconcentration, concentration and »concentrated deconcentration «.

Three different types of peripheral areas according to economic activity in the last 150 years have been defined:

- areas conserving »the memory « of the economic prosperity in the past;

- areas combining local economy with the employment outside the area,

- areas being permanently in dependent relation with the vicinity, conserving autarktic agriculture production.

The areas flowerishing in economy in the past have had preserved a positive identity, being helpfully for contemporary development.

Seasonal employment contributes usually to the diffusion of innovations in the peripheral areas. 